\title{
COMPARATIVE STUDY OF INCIDENCE RATES AND ANTIBIOGRAM OF CATHETER-ASSOCIATED URINARY TRACT INFECTIONS IN INTENSIVE CARE UNIT VERSUS NON-INTENSIVE CARE UNIT AT A TERTIARY CARE TEACHING HOSPITAL
}

\author{
MICAH JOB, MOBISHA MONACHAN*, RESMI SCARIA, MERLIN BABU
}

Department of Pharmacy Practice, Bapuji Pharmacy College, Davangere, Karnataka, India. Email: mobishamonachan@gmail.com

Received: 04 March 2021, Revised and Accepted: 20 May 2021

\section{ABSTRACT}

Objective: Catheter-associated urinary tract infections (CAUTI) is the most common HAI which leads to increased hospital stay and morbidity. The study aimed to compare the incidence rates of CAUTI per 1000 catheter days and their antimicrobial susceptibility pattern between ICU and non ICU and to determine predisposing risk factors, indications, and outcomes of CAUTI.

Methods: A comparative observational study was conducted in ICU and non ICU for a period of 6 months. The sample size of the study was 120 . The data were collected, analyzed in terms of both inferential and descriptive statistics.

Results: The incidence rate per thousand catheter days in non ICU was more as compared to ICU. The significant risk factors associated with CAUTI were the duration of catheterization and type 2 diabetes mellitus. The majority of the patients were catheterized for indications such as critically ill and unconsciousness followed by measurement of urine output. The outcomes of CAUTI were increased duration of hospitalization and recovery of patients. All the Gram-positive and Gram-negative isolates from non ICU were sensitive to piperacillin + tazobactam and meropenem. All the isolates from ICU and non ICU were resistant to co-trimoxazole.

Conclusion: The urinary catheter is an essential part of modern medical care. Unfortunately, when used inappropriately or when left in place for too long, it is a hazard to the patient. This study helps to prevent indiscriminate and irrational use of antibiotics which contribute to emerging of drug resistance strains.

Keywords: Catheter-associated urinary tract infections, Hospital Acquired Infection, Urinary catheter, Uropathogens.

(c) 2021 The Authors. Published by Innovare Academic Sciences Pvt Ltd. This is an open access article under the CC BY license (http://creativecommons.org/ licenses/by/4.0/) DOI: http://dx.doi.org/10.22159/ajpcr.2021v14i6.41293. Journal homepage: https://innovareacademics.in/journals/index.php/ajpcr

\section{INTRODUCTION}

According to the World Health Organization, a Hospital Acquired Infection (HAI) is "an infection acquired in a hospital by a patient who was admitted for a reason other than that infection."[1]. The most frequent HAI is catheter-associated urinary tract infections (CAUTI) accounting for 36\%, followed by surgical site infections, central line-associated bloodstream infections, and ventilator-associated infections [2].

CAUTI is defined by CDC as any urinary tract infection in a patient who had an indwelling catheter in place at the time of or within $48 \mathrm{~h}$ before onset of infection with at least one of the following signs or symptoms: Fever $\left(>38^{\circ} \mathrm{C}\right)$, urgency, frequency, dysuria, suprapubic tenderness, costovertebral angle pain or tenderness, and a positive urine culture of $\geq 10^{5}$ colony-forming units $/ \mathrm{ml}$ with no more than two species of microorganisms [3]. CAUTI constitutes $40-50 \%$ of all hospital infections [4]. The incidence of CAUTI is directly proportional to the number of catheter days [5]. As the duration of catheterization in intensive care unit (ICU) is more, the frequency of CAUTI is expected to be higher.

Risk factors in the development of a CAUTI identified so far are female gender, obesity, immune deficiency, duration of catheter use, length of hospital stay, and unnecessary placement of urinary catheters [6]. Duration of catheterization remains a significant factor in predicting CAUTI and each day of catheterization increases the risk of CAUTI by $3-10 \%$ [7]. The most important predisposing factor for CAUTI is the insertion of the urinary catheter $[5,8]$.

CAUTIs can be caused by several bacterial species including uropathogenic Escherichia coli (UPEC), Staphylococcus saprophyticus,
Klebsiella pneumoniae, Enterococcus faecalis, Group B Streptococcus, Staphylococcus aureus, Proteus mirabilis, Pseudomonas aeruginosa, and Enterobacter spp. However, the most common causative organism for UTI and CAUTI is UPEC. It is estimated that UPEC is responsible for approximately $80 \%$ of all UTIs [9]. The microbiological profile and antimicrobial sensitivity pattern of CAUTI vary considerably from time to time and region to region [10].

CAUTI has been associated with a threefold increased risk of mortality in hospitals because of the inappropriate use of antimicrobial agents leading to the spread of antimicrobial resistance and the emergence of multidrug-resistant uropathogens [11].

The objectives of our study were to compare the incidence rates of CAUTI per 1000 catheter days between ICU and non ICU patients, to identify the risk factors and to correlate its relative risk with CAUTI, to identify the outcomes of CAUTI and indications of catheterization and to compare the antibiotic sensitivity pattern of uropathogens isolated from confirmed cases of CAUTI between ICU and non ICU patients.

\section{MATERIALS AND METHODS}

\section{Study design and population}

We conducted a comparative observational study among 60 ICU and 60 non ICU inpatients at Shamanur Shivashankarapa Institute of Medical Sciences and Research Center, Davangere, Karnataka, for a period of 6 months. Ethical approval for the study was obtained from the Institutional Ethics Committee of Bapuji Pharmacy College, Davangere, Karnataka.

This study included patients admitted to ICU and non ICU who had the indwelling catheters in place for at least $48 \mathrm{~h}$ and patients of either 
Table 1: Distribution of subjects based on incidence rate per 1000 catheter days in ICU and non ICU

\begin{tabular}{lll}
\hline Department & $\begin{array}{c}\text { Catheter-associated } \\
\text { urinary tract infections +ve }\end{array}$ & $\begin{array}{l}\text { Incidence rate per } \\
\mathbf{1 0 0 0} \text { catheter days }\end{array}$ \\
\hline $\begin{array}{l}\text { ICU } \\
(\mathrm{n}=60)\end{array}$ & 6 & 16.17 \\
$\begin{array}{l}\text { non ICU } \\
(\mathrm{n}=60)\end{array}$ & 7 & 20 \\
\hline
\end{tabular}

ICU: Intensive care unit

Table 2: Distribution of cases based on gender

\begin{tabular}{lllll}
\hline Gender & $\begin{array}{l}\text { No. of } \\
\text { subjects } \\
\text { n=120 }\end{array}$ & Percentage & $\begin{array}{l}\text { Catheter-associated } \\
\text { urinary tract } \\
\text { infections +ve n=13 }\end{array}$ & Percentage \\
\hline Male & 80 & 66.7 & 10 & 77 \\
Female & 40 & 33.3 & 3 & 23 \\
\hline
\end{tabular}

Table 3: Distribution of cases based on age

\begin{tabular}{lllll}
\hline $\begin{array}{l}\text { Age } \\
\text { (years) }\end{array}$ & $\begin{array}{l}\text { No: of } \\
\text { subjects } \\
\mathbf{n = 1 2 0}\end{array}$ & Percentage & $\begin{array}{l}\text { Catheter-associated } \\
\text { urinary tract } \\
\text { infections +ve } \mathbf{n = 1 3}\end{array}$ & Percentage \\
\hline$<18$ & 13 & 11 & - & - \\
$18-30$ & 10 & 8 & 1 & 7.6 \\
$31-40$ & 11 & 9 & 1 & 7.6 \\
$41-50$ & 12 & 10 & - & - \\
$51-60$ & 19 & 16 & 4 & 31 \\
$>60$ & 55 & 46 & 7 & 53.8 \\
\hline
\end{tabular}

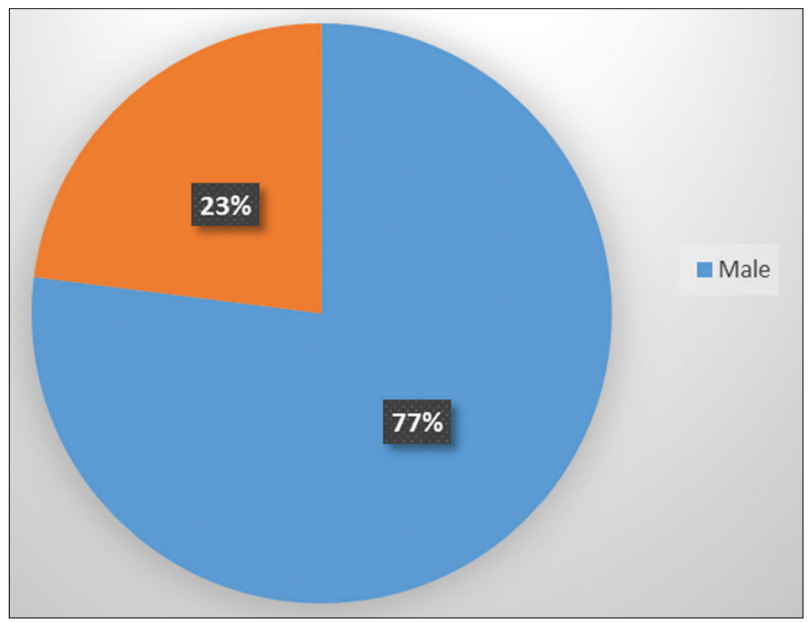

Fig. 1: Distribution of catheter-associated urinary tract infections cases based on gender

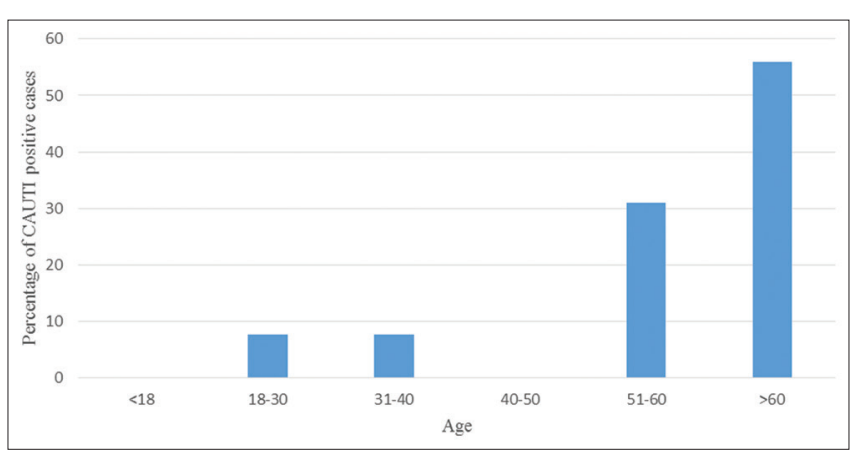

Fig. 2: Distribution of catheter-associated urinary tract infections cases based on age sex of all age groups. This study excluded all the subjects whose initial urine culture at the onset of catheterization was positive, intermittent catheterization, pregnant women, recurrent UTI patients, and patients transferred from other hospitals with a catheter.

All the data required for the study were collected from the patient's case sheets. The patient was followed up till they remove the catheter. The demographic details, drugs prescribed, details of catheterization, and culture sensitivity results were recorded in a properly designed data collection form. All the collected data were analyzed for risk factors, outcomes of CAUTI, indications of catheterization, and for the comparison of incidence rates and antibiogram among ICU versus non ICU.

\section{Statistical analysis}

All the collected data were gathered in the form of an excel spreadsheet with all protected health information that was removed prior to any statistical analysis. Data analysis was done through IBM SPSS Statistics, Version 23.0. Pearson correlation matrices were used to evaluate for relationship within data. $\mathrm{p} \leq 0.05$ was used to determine the statistical significance.

\section{RESULTS}

A total number of 120 patients were enrolled in the study. Among that 60 were from ICU and 60 from non ICU. Out of 13 confirmed CAUTI cases that occurred during the study period, seven CAUTI cases were from non ICU patients and 6 were from ICU patients. The incidence rate per thousand catheter days in non ICU was more as compared to ICU and it was found to be 20 and 16.17, respectively (Table 1).

Out of 120 subjects, $66.7 \%$ of the studied population were males and $33.3 \%$ were females. The rate of CAUTI was more in males than in females (Fig. 1 and Table 2).

Most of the subjects belonged to the age group of above 60 years (46\%). The mean age of patients included in the study was 51.49 . The incidence

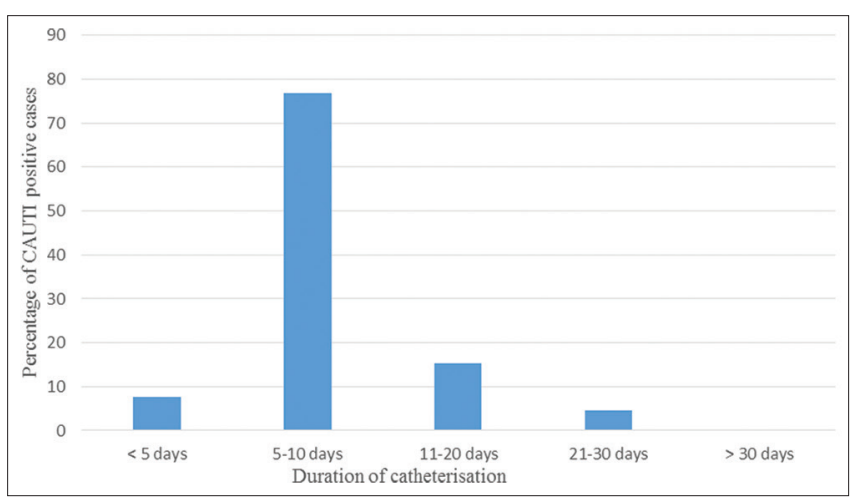

Fig. 3: Distribution of catheter-associated urinary tract infections cases based on duration of catheterization

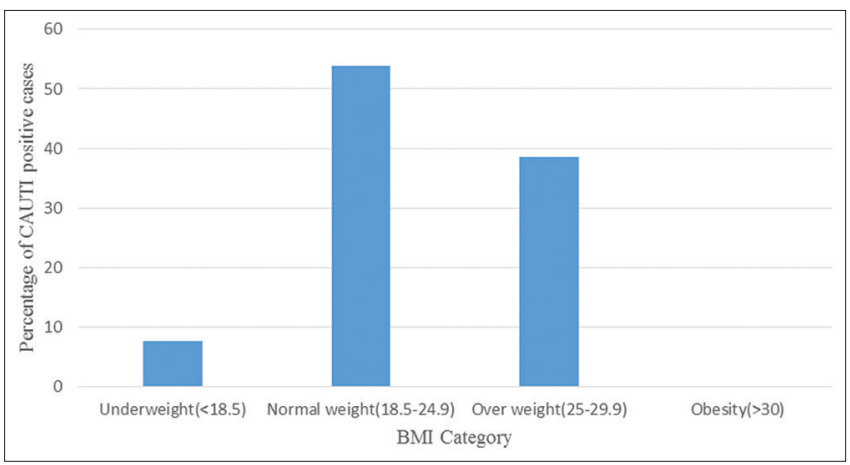

Fig. 4: Distribution of catheter-associated urinary tract infections cases based on body mass index 
Table 4: Distribution of cases based on duration of catheterization

\begin{tabular}{lllll}
\hline $\begin{array}{l}\text { Duration of } \\
\text { catheterization }\end{array}$ & $\begin{array}{l}\text { No. of } \\
\text { subjects } \\
\mathbf{n = 1 2 0}\end{array}$ & $\begin{array}{l}\text { Percentage } \\
\mathbf{( \% )}\end{array}$ & $\begin{array}{l}\text { CAUTI } \\
+\mathbf{v e} \\
\mathbf{n = 1 3}\end{array}$ & Percentage \\
\hline$<5$ days & 41 & 34.1 & 1 & 7.7 \\
5-10 days & 71 & 59.2 & 10 & 76.9 \\
11-20 days & 8 & 6.7 & 2 & 15.4 \\
21-30 days & - & - & - & - \\
$>30$ days & - & - & - & - \\
\hline
\end{tabular}

Table 5: Distribution of cases based on BMI

\begin{tabular}{lllll}
\hline BMI category & $\begin{array}{l}\text { No: of } \\
\text { subjects } \\
\mathbf{n = 1 2 0}\end{array}$ & Percentage & $\begin{array}{l}\text { Catheter- } \\
\text { associated } \\
\text { urinary tract } \\
\text { infections } \\
\text { +ve } \mathbf{n = 1 3}\end{array}$ & Percentage \\
\hline $\begin{array}{l}\text { Underweight } \\
(<18.5)\end{array}$ & 22 & 18.3 & 1 & 7.6 \\
$\begin{array}{l}\text { Normal } \\
\text { weight }\end{array}$ & 56 & 46.7 & 7 & 53.9 \\
$\begin{array}{l}\text { (18.5-24.9) } \\
\text { Over weight }\end{array}$ & 37 & 30.8 & 5 & 38.5 \\
$\begin{array}{l}(25-29.9) \\
\text { Obesity }(>30)\end{array}$ & 3 & 2.5 & - & - \\
\hline
\end{tabular}

BMI: Body mass index

Table 6: Distribution of catheter-associated urinary tract infections cases based on their co-morbid condition

\begin{tabular}{llll}
\hline Co-morbidity & $\begin{array}{l}\text { No. of } \\
\text { subjects }\end{array}$ & $\begin{array}{l}\text { Catheter- } \\
\text { associated urinary } \\
\text { tract infections +ve }\end{array}$ & Percentage \\
\hline $\begin{array}{l}\text { Type 2 diabetes } \\
\text { mellitus }\end{array}$ & 43 & 9 & 69.2 \\
$\begin{array}{l}\text { Hypertension } \\
\text { Chronic kidney }\end{array}$ & 43 & 7 & 53.8 \\
$\begin{array}{l}\text { disease } \\
\begin{array}{l}\text { Ischemic heart } \\
\text { disease }\end{array}\end{array}$ & 6 & 3 & 23 \\
$\begin{array}{l}\text { Chronic obstructive } \\
\text { pulmonary disease }\end{array}$ & 2 & 1 & 7.6 \\
$\begin{array}{l}\text { Seizure } \\
\text { Tuberculosis }\end{array}$ & 1 & 1 & 7.6 \\
\hline
\end{tabular}

of CAUTI was common in patients above 60 years of age (53\%) (Fig. 2 and Table 3).

Majority of the patients were catheterized for 5-10 days and the rate of CAUTI was more in 5-10 days of catheterization (Fig. 3 and Table 4).

The greater number of subjects included in the study was having normal weight and the rate of CAUTI was more in normal-weight patients (Fig. 4 and Table 5).

The most common co-morbidities in catheterized patients were found to be hypertension and Type 2 diabetes mellitus (DM) in which Type 2 DM was more prominent among CAUTI patients (69.2\%) (Table 6).

Duration of catheterization and Type 2 DM had a significant association with CAUTI, with $\mathrm{p}=0.04$ and 0.01 , respectively, whereas age, sex, and BMI had no significant association with CAUTI (Table 7).

The outcomes of CAUTI were increased duration of hospitalization in $62 \%$ of patients and recovery in $38 \%$ of patients (Table 8 ).

The majority of the patients were catheterized for other indications such as critically ill and unconsciousness, followed by measurement of urine output (Table 9).

A total of five microorganisms were isolated from 13 cases of CAUTI. Among the bacterial isolates, Gram-negative bacilli predominate. Uropathogens isolated from ICU include E. coli, MRSA, methicillinresistant coagulase-negative staphylococci, $K$. pneumonia, and Pseudomonas species whereas in case of the non ICU, E. coli, Klebsiella, and Pseudomonas were the isolated organisms (Table 10).

All the Gram-positive isolates from ICU were sensitive to linezolid whereas all the Gram-positive and Gram-negative isolates from non ICU were sensitive to piperacillin + tazobactam and meropenem (Table 11).

The incidence of antibiotic resistance was high in all the isolated organisms. All the Gram-positive and Gram-negative isolates from non-ICU and Gram-positive isolate from ICU were resistant to cotrimoxazole (Table 12).

\section{DISCUSSION}

CAUTI is the most common nosocomial infection which constitutes a major source of nosocomial septicemia and related mortality in acute care hospitals. In our study, it was found that the incidence rate of CAUTI per 1000 catheter days is more in non ICU patients than ICU patients.

Table 7: Correlation of risk factors to CAUTI

\begin{tabular}{|c|c|c|c|c|c|c|}
\hline \multirow[t]{2}{*}{ Age group } & \multicolumn{4}{|l|}{ CAUTI } & \multirow[t]{2}{*}{ Odd's ratio $(95 \% \mathrm{CI})$} & \multirow[t]{2}{*}{$\mathbf{p}$} \\
\hline & +ve $n=13$ & $\%$ & -ve $n=107$ & $\%$ & & \\
\hline$<18$ & - & - & 13 & 12.4 & $1.02(0.97-1.06)$ & 49 (NS) \\
\hline $31-40$ & 1 & 7.6 & 10 & 9.3 & & \\
\hline $41-50$ & - & - & 12 & 11.2 & & \\
\hline $51-60$ & 4 & 30.7 & 15 & 14.01 & & \\
\hline$>60$ & 7 & 53.84 & 48 & 44.85 & & \\
\hline \multicolumn{7}{|l|}{ Sex } \\
\hline Male & 10 & 76.92 & 70 & 65.42 & $0.57(0.15-2.19)$ & $0.54(\mathrm{NS})$ \\
\hline Female & 3 & 23.07 & 37 & 34.57 & & \\
\hline BMI & $23.63 \pm 3$ & & $23.35 \pm 4.36$ & & $0.97(0.83-1.13)$ & $0.71(\mathrm{NS})$ \\
\hline \multicolumn{7}{|l|}{ Duration of catheterization } \\
\hline$<5$ days & 1 & 7.6 & 40 & 37.38 & $1.23(1.01-1.48)$ & $0.04^{*}$ \\
\hline 5-10 days & 10 & 76.9 & 61 & 57 & & \\
\hline 11-20 days & 2 & 15.38 & 6 & 5.6 & & \\
\hline 21-30 days & - & - & - & - & & \\
\hline Type 2 diabetes mellitus & 9 & 69.2 & 34 & 31.77 & $4.83(1.39-16.80)$ & $0.01^{*}$ \\
\hline
\end{tabular}

${ }^{*} \mathrm{p}<0.05$ Statistically Significant, $\mathrm{p}>0.05$. NS: Non significant 
The decreased rate of CAUTI in ICU might be due to the increased aseptic environment than non ICU. A similar study conducted by Zahran et al. [12]. on the comparison of the incidence rate of CAUTI among ICU and non ICU patients had found that the incidence rate is more in non ICU.

Risk factors associated with the development of CAUTI include female gender, age, impaired immunity, co-morbidity, and increased duration

Table 8: Distribution of cases based on outcomes of CAUTI

\begin{tabular}{lll}
\hline Outcome & CAUTI +ve n=13 & Percentage \\
\hline Died & - & - \\
Recovered & 5 & 38 \\
Increased stay of hospitalization & 8 & 62 \\
Complications & - & - \\
\hline
\end{tabular}

CAUTI: Catheter-associated urinary tract infections

Table 9: Distribution of cases based on indications of catheterization

\begin{tabular}{lll}
\hline Indications of catheterization & $\begin{array}{l}\text { No. of subjects } \\
\mathbf{n = 1 2 0}\end{array}$ & Percentage \\
\hline Measurement of urine output & 25 & 20.83 \\
Perioperative drainage & 1 & 0.84 \\
Urinary incontinence & 6 & 5 \\
Urinary retention & 13 & 10.84 \\
Others & 75 & 62.5 \\
\hline
\end{tabular}

Table 10: Distribution of CAUTI cases based on bacterial isolates from ICU and non ICU

\begin{tabular}{|c|c|c|c|}
\hline \multirow[t]{2}{*}{ Isolated organism } & \multicolumn{2}{|c|}{$\begin{array}{l}\text { No. of CAUTI } \\
\text { subjects }\end{array}$} & \multirow[t]{2}{*}{ Total } \\
\hline & ICU & Non ICU & \\
\hline Escherichia coli & 2 & 4 & 6 \\
\hline Methicillin-resistant Staphylococcus aureus & 1 & & 1 \\
\hline $\begin{array}{l}\text { Methicillin-resistant coagulase -ve } \\
\text { staphylococci }\end{array}$ & 1 & - & 1 \\
\hline Klebsiella pneumonia & 1 & 2 & 3 \\
\hline Pseudomonas species & 1 & 1 & 2 \\
\hline
\end{tabular}

CAUTI: Catheter-associated urinary tract infections, ICU: Intensive care unit of catheterization [6]. On the contrary, our study found no significant association of CAUTI with age, gender, and BMI. Out of 13 CAUTI patients, $77 \%$ were male and $23 \%$ were female. This result was in concordance with the study conducted by Sandhu et al. [9]. This result might be due to a greater number of male samples as compared to female samples received and males are prone to obstructive urinary lesion especially from benign prostate hypertrophy and stricture associated with advanced age.

The incidence of CAUTI cases increases with the age of the patient. This might be due to the age-associated changes in immune function, exposure to nosocomial pathogens, and increased number of comorbidities in the elderly. Garibaldi et al. [13] noted that patients over the age of 50 years had approximately a two-fold incidence of bacteriuria and they concluded that advanced age is responsible for the high prevalence of catheter-associated bacteriuria. Similarly, Kulkarni et al. [14] found that patients aged 40 years and more were having more risk of developing CAUTI than those who were aged $<40$ years.

The duration of catheterization was found to be a significant risk factor of CAUTI. A similar study was conducted by Leelakrishna and Karthik [15] also revealed the same result. The longer the catheter is placed, the higher is the incidence of urinary tract infection. The incidence of bacteriuria in catheterized patients is directly related to the duration of catheterization; the daily rate of acquiring bacteriuria is approximately $3-10 \%$. In our study, we found that the rate of CAUTI was more in 5-10 days of catheterization.

In the present study, we found that patients with DM had a 4.83 times more risk of developing CAUTI than those without DM. Various impairments in the immune system, poor metabolic control, and incomplete bladder emptying due to autonomic neuropathy may all contribute to the enhanced risk of CAUTI in these patients. Sugar in the urine also promotes bacterial growth. This finding is comparable with the study conducted by Kulkarni et al. [14] and Platt et al. [16] and noted an increased risk of acquiring infection among individuals with diabetics.

In the present study, the outcomes of CAUTI were increased duration of hospitalization and recovery of patients whereas a similar study conducted by Zahran et al. [12] found that the outcomes of CAUTI were complete recovery among $98.5 \%$ of patients.

In most of the studies done in UTI till today, the most common organism isolated is $E$. coli. However, there is a reduction in the frequency of $E$. coli (although it remains the usual cause) in patients with indwelling

Table 11: Distribution of isolates sensitive toward antibiotics from ICU and non ICU

\begin{tabular}{|c|c|c|c|c|c|c|c|c|}
\hline Sensitive antibiotics & \multicolumn{2}{|c|}{ Escherichia coli } & $\begin{array}{l}\text { Methicillin-resistant } \\
\text { Staphylococcus } \\
\text { aureus } \\
\text { ICU }\end{array}$ & $\begin{array}{l}\text { Methicillin- } \\
\text { resistant coagulase } \\
\text {-ve staphylococci } \\
\text { ICU }\end{array}$ & \multicolumn{2}{|c|}{ Klebsiella pneumonia } & \multicolumn{2}{|c|}{ Pseudomonas species } \\
\hline Amikacin & 2 & 3 & - & 1 & - & - & 0 & 1 \\
\hline Gentamycin & 1 & 2 & - & 1 & - & - & - & - \\
\hline Imipenem & 1 & 2 & - & - & 1 & 1 & - & - \\
\hline Meropenem & 2 & 1 & - & - & - & 2 & - & 1 \\
\hline Linezolid & & 1 & 1 & 1 & 1 & 1 & - & - \\
\hline Vancomycin & 1 & 1 & 1 & - & - & - & - & - \\
\hline Ciprofloxacin & - & 1 & - & 1 & - & - & - & - \\
\hline Nitrofurantoin & 1 & - & 1 & - & - & 1 & - & - \\
\hline Norfloxacin & 1 & - & - & - & - & - & - & - \\
\hline Levofloxacin & 1 & - & - & - & - & - & - & - \\
\hline Ceftazidime & - & - & - & - & - & 1 & - & - \\
\hline Ampicillin & - & - & - & - & - & - & 1 & - \\
\hline Cefotaxime & - & - & - & - & - & - & 1 & - \\
\hline Ceftriaxone & - & - & - & - & - & - & - & 1 \\
\hline
\end{tabular}

ICU: Intensive care unit 
Table 12: Distribution of isolates resistance toward antibiotics from ICU and non ICU

\begin{tabular}{|c|c|c|c|c|c|c|c|c|}
\hline \multirow[t]{2}{*}{ Resistant antibiotics } & \multicolumn{2}{|c|}{ Escherichia coli } & \multirow{2}{*}{$\begin{array}{l}\text { Methicillin-resistant } \\
\text { Staphylococcus aureus } \\
\text { ICU }\end{array}$} & \multirow{2}{*}{$\begin{array}{l}\text { Methicillin- resistant } \\
\text { coagulase -ve staphylococci } \\
\text { ICU }\end{array}$} & \multicolumn{2}{|c|}{$\begin{array}{l}\text { Klebsiella } \\
\text { pneumonia }\end{array}$} & \multicolumn{2}{|c|}{ Pseudomonas species } \\
\hline & ICU & Non ICU & & & ICU & Non ICU & ICU & Non ICU \\
\hline Cefotaxime & 2 & 2 & - & - & - & 1 & - & - \\
\hline Ciprofloxacin & 1 & 4 & 1 & - & - & 1 & - & - \\
\hline Co-trimoxazole & 1 & 3 & 1 & 1 & 1 & 1 & - & 1 \\
\hline Clindamycin & - & 1 & 1 & 1 & - & - & - & - \\
\hline Doxycycline & - & - & - & 1 & - & - & - & - \\
\hline Tetracycline & 2 & 1 & - & 1 & 1 & - & - & 1 \\
\hline Amikacin & - & - & 1 & - & - & 1 & - & - \\
\hline Levofloxacin & 1 & 1 & - & - & - & - & - & - \\
\hline Ceftazidime & - & - & - & - & - & 1 & - & - \\
\hline Ampicillin & - & - & - & - & 1 & 1 & - & 1 \\
\hline Ceftriaxone & 1 & - & - & - & 1 & - & - & - \\
\hline Nitrofurantoin & - & - & - & - & 1 & - & - & - \\
\hline Meropenem & - & - & - & - & 1 & - & - & - \\
\hline Amoxicillin clavulanate & - & 3 & - & - & - & - & - & - \\
\hline
\end{tabular}

ICU: Intensive care unit

catheters. A similar finding was seen in our study where the most common isolate was $E$. coli followed by Klebsiella in ICU as well as non ICU. This observation seems to agree with several other studies with $E$. coli isolation rate ranged from $22 \%$ to $40.47 \%$ [17].

Regarding susceptibility, all the Gram-positive isolates from ICU were sensitive to linezolid whereas all the Gram-positive and Gram-negative isolates from non ICU were sensitive to piperacillin + tazobactam and meropenem. All the Gram-positive and Gram-negative isolates from non-ICU and Gram-positive isolates from ICU were resistant to cotrimoxazole.

\section{CONCLUSION}

The urinary catheter is an essential part of the modern medical care. Unfortunately, when used inappropriately or when left in place for too long, it is a hazard to the patient. The urinary tract of a catheterized patient is highly susceptible to severe infection resulting in increased hospitalization, medication, morbidity and also adds to the financial burden. This study provides the data on incidence rate, predisposing risk factors, and the causative microbial flora along with the information of susceptibility pattern of the organisms. This will help us in the selection of appropriate antibiotics for therapeutic use and to prevent indiscriminate and irrational use of antibiotics which contribute to emerging of drug resistance strains in the environment. The incidence of CAUTI per 1000 catheter days was more in non ICU as compared to ICU. It is widely accepted that the risk for CAUTI is proportional to the number of days a catheter remains indwelling. Therefore, reduction of indwelling catheter days is a cornerstone of any CAUTI prevention, in our study, we found that duration of catheterization and Type 2 DM had a significant association with CAUTI. All patients with urinary catheters for more than 6 days, aged 60 , and above should be checked for UTI symptoms and their urine should be cultured regularly to diagnose and prevent CAUTI and its complications. The most important risk factors of CAUTI are improper indication and duration of catheterization. Although not all CAUTIs can be prevented, it is believed that the incidence can be reduced through active surveillance and by the proper management of the indwelling catheter. Most hospitals do not have strict guidelines for the prevention of CAUTI. Therefore, the health-care professionals should have adequate knowledge regarding catheter indications and CAUTI prevention.

\section{ACKNOWLEDGMENT}

We are also highly obliged to the subjects who gave us consent for submission of the manuscript. We would like to express our gratitude towards Dr. Akhila S Arjun who guided us throughout the entire process and also to the subjects who gave consent for our study.

\section{AUTHORS CONTRIBUTION}

Resmi Scaria and Merlin Babu contributed in writing the manuscript whereas Micah Job and Mobisha Monachan provided the particulars and details of the subjects.

\section{CONFLICT OF INTEREST}

There is no conflict of interest between the authors.

\section{AUTHORS FUNDING}

None.

\section{REFERENCES}

1. Nag K, Datta A, Karmakar N, Chakraborty T. Knowledge, attitude and practice about hospital acquired infection among health care personnel in a tertiary care hospital of Tripura. Int J Med Health Res 2018;6:3303-8.

2. Mukakamanzi J. Knowledge, Attitude and Practices of Nurses Towards the Prevention of Catheter-Associated Urinary Tract Infection in Selected Referral Hospitals in Rwanda [Dissertation]. Rwanda: University of Rwanda; 2017.

3. Verma S, Naik SA, Deepak TS. Etiology and risk factors of catheter associated urinary tract infections in ICU patients. IP Int J Med Microbiol Trop Dis 2017;3:65-70.

4. Kazi MM, Harshe A, Sale H, Mane D, Minal Y, Chabukswar S. Catheter associated urinary tract infections (CAUTI) and antibiotic sensitivity pattern from confirmed cases of CAUTI in a tertiary care hospital: A prospective study. Clin Microbiol 2015;4:193.

5. Jain M, Dogra V, Mishra B, Thakur A, Loomba PS. Knowledge and attitude of doctors and nurses regarding indication for catheterization and prevention of catheter-associated urinary tract infection in a tertiary care hospital. Indian J Crit Care Med 2015;19:76.

6. Mohammadzadeh M, Behnaz F. Incidence and risk factors of catheter associated urinary tract infection in Yazd-Iran. Int $J$ Urol Nurs 2012;6:60-5

7. Vinoth M, Prabagaravarthanan R, Bhaskar M. Prevalence of microorganisms causing catheter associated urinary tract infections (CAUTI) among catheterized patients admitted in a tertiary care hospital. Int J Res Med Sci 2017;5:2367-72.

8. Khan MY, Venkateshwarlu C, Sreenivas G, Rahul P. Study of incidence and risk factors of urinary tract infection in catheterized patients admitted at tertiary care hospital, Nizamabad, Telangana State, India. Int Arch Integr Med 2016;3:83-92.

9. Sandhu R, Sayal P, Jakkhar R, Sharma G. Catheterization-associated urinary tract infections: Epidemiology and incidence from tertiary care hospital in Haryana. J Health Res Rev 2018;5:135.

10. Hanumantha S, Pilli HP. Catheter associated urinary tract infection (CAUTI) incidence and microbiological profile in a tertiary care hospital in Andhra Pradesh. Indian J Microbiol Res 2016;3:453-6. 
11. Mojtahedzadeh M, Panahi Y, Fazeli MR, Najafi A, Pazouki M, Navehsi BM, et al. Intensive care unit-acquired urinary tract infections in patients admitted with sepsis: Etiology, risk factors, and patterns of antimicrobial resistance. Int J Infect Dis 2008;12:312-8.

12. Zahran FE, Alhommos AK, Elkohafy SA, Ibrahim A, Mohamed GK, Alhommos AK. Catheter associated urinary tract infection (CAUTI) in Medical Ward, and ICU KFHH during year 2017. Int J Adv Res 2018;6:997-1011.

13. Garibaldi RA, Burke JP, Dickman ML, Smith CB. Factors predisposing to bacteriuria during indwelling urethral catheterization. N Engl J Med 1974;291:215-9.
14. Kulkarni DS, Talib DS, Naik DM, Kale DA. Profile of urinary tract infection in indwelling catheterized patients. IOSR J Dent Sci 2014;13:132-8.

15. Leelakrishna P, Karthik RB. A study of risk factors for catheter associated urinary tact infection. Inj J Adv Med 2018;5:334-9.

16. Platt R, Polk BF, Murdock B, Rosner B. Mortality associated with nosocomial urinary-tract infection. N Engl J Med 1982;307:637-42.

17. Karkee P, Dhital D, Madhup SK, Sherchan JB. Catheter associated urinary tract infection: Prevalence, microbiological profile and antibiogram at a tertiary care hospital. Clin Chem Lab Med 2017;3:3-10. 